Journal Of Ageing And Family (JOAF)

Edition 1, No 1, October 2021

\title{
Factors Associated With Dementia In The Elderly At Cakung District Health Center In
} 2020

\author{
Tasya Virrisya Tania*, Fajar Susanti, Erlin Ifadah, Aprisunadi \\ Nursing Study Program, Faculty of Health Sciences \\ University Respati Indonesia
}

\begin{abstract}
Dementia is an acquired intellectual and memory dysfunction caused by brain disease, and is not associated with impaired levels of consciousness. The purpose of this study was to determine the factors associated with dementia in the elderly at the Cakung District Health Center in 2020. This study is a quantitative study with a correlative descriptive research design with a cross sectional study approach. The population consisted of elderly patients who participated in prolanis activities at the Cakung District Health Center. Sampling using total sampling. The sample consisted of 60 respondents. Data analysis using chi square test. The results showed a relationship between age $(p=0.000)$, physical activity $(p=0.000)$ and dementia. Physical activity needs to be done by the elderly to inhibit the factors that accelerate the onset of dementia. Counseling and learning about physical activity in the elderly should be a program in providing health services to the elderly, especially to prevent dementia.
\end{abstract}

Keywords : Dementia, Physical Activity

Background

Dementia is an acquired impairment of intellectual function and memory caused by a brain disease, and is not associated with an impaired level of consciousness. The incidence of dementia increases with increasing age. After age 65, the prevalence of dementia doubles for every 5 years of age. The overall prevalence of dementia in the population aged over 60 years is $5.6 \%$. Currently, life expectancy is increasing, it is expected that the prevalence of dementia will also increase. Worldwide, 35.6 million people have dementia with more than half (58\%) living in low- and middle-income countries (WHO, 2011). Based on the Alzheimer's Disease International Report (2014), the prevalence of dementia in the world was 44.4 million in 2013. At the age of 65 years, about $7 \%$ of the elderly population had dementia, while at the age of 75-85 years the incidence of dementia in the elderly increased by two. doubled to $14 \%$. The 
increase in the incidence of dementia occurs with increasing age. Shah's research in 2014 said the prevalence of dementia doubles for every 5.1 year increase in age after 60 years in developed countries and every 7.3 years in developing countries. The incidence of dementia in Indonesia itself is quite high, reaching 4.07 million people (Yudhanti, 2016). Indonesia according to health profile data reported by the Ministry of Health in 2011 , there are $7.1 \%$ of the population aged 60 years and over suffer from dementia. The increase in the incidence of dementia cases is directly proportional to the increase in the life expectancy of a population (Hidayaty, 2012). Data from the 2013 World Alzheimer's Report predicts that the number of elderly dependents will increase from 101 million to 177 million by 2050 . Nearly half are living with Alzheimer's disease or other types of dementia, which will quickly become a global health crisis (Aminuddin, 2015). Alzheimer's dementia (senile) is a degenerative disease where there is a decrease in brain function that affects emotions, memory, decision making, behavior and other brain functions so that it interferes with daily activities (Meter, 2016). Dementia in the elderly has many risk factors, such as age, education level, blood pressure, nutritional intake, genetics, gender and lack of physical activity. Physical activity done to fill leisure time in the elderly can reduce the risk of dementia. According to research by Dr. R.W Bowers, after 10 weeks of jogging, from those who previously just sat alone, it turned out to be able to improve memory and think sharper (Hidayaty, 2012). Physical activity can stimulate neuronal growth factors that enable these factors that inhibit cognitive function and dementia. Many changes occur in the elderly, including changes in the body, muscles, bones and joints, cardiovascular system, respiration, and cognition (Ambardini, 2016). Lack of physical activity is an independent risk factor for chronic diseases and overall is estimated to cause death globally (WHO, 2010). Research conducted by Sri Suwarni (2017) shows that there is a relationship between age and dementia. Research conducted by Yudhanti (2016) showed that there was a significant relationship between physical activity and the incidence of dementia in the elderly at the Tresna Werdha Social Service Center Yoyakarta Budi Luhur Unit because the number of elderly dementia with less physical activity was around (79.5\%). A preliminary study conducted on March 11, 2020 on elderly patients at the Public Health 
Center in Cakung District, from 15 patients who were observed using the Mini Mental Status Examination (MMSE), found that 11 elderly people suffered from dementia. Based on interviews with some elderly people with dementia, as many as 5 people, some elderly people with dementia said they rarely did physical activity because of physical limitations.

\section{Research methods}

This type of research is quantitative with a descriptive correlative research design with a cross sectional approach. The study was conducted at the Cakung District Health Center, East Jakarta, from August 2020 to December 2020. The population in this study were all elderly patients who took part in prolanis activities at the Cakung District Health Center as many as 60 people. Sampling used by researchers is Non Probability Sampling with total sampling technique. The sample in this study amounted to 60 respondents. Data analysis carried out includes univariate and bivariate analysis.

Research result
Table 1 Frequency Distribution of Respondents by Gender $(\mathbf{n}=60)$

\begin{tabular}{lll}
\hline Jenis Kelamin & Jumlah & Presentase (\%) \\
\hline Laki-laki & 43 & 71,7 \\
Perempuan & 17 & 28,3 \\
\hline Total & 60 & 100 \\
\hline
\end{tabular}

Table 1 shows the frequency distribution of respondents by gender, namely respondents with male sex amounting to $43(71.7 \%)$, respondents with female sex totaling 17 $(28.3 \%)$

Table 2. Frequency Distribution of Respondents by Age Category $(n=60)$

\begin{tabular}{lll}
\hline Kategori Usia & Jumlah & Presentase (\%) \\
\hline Lansia Awal & 40 & 66,7 \\
Lansia Akhir & 20 & 33,3 \\
\hline Total & 60 & 100 \\
\hline
\end{tabular}

Table 2 shows the frequency distribution of respondents based on age categories, namely respondents with the early elderly age category totaling $40(66.7 \%)$, respondents with the late elderly age category totaling 20 (33.3\%). 
Table 3. Frequency Distribution of Respondents Based on Physical Activity $(\mathrm{n}=60)$

\begin{tabular}{lll}
\hline Aktivitas Fisik & Jumlah & Presentase (\%) \\
\hline Baik & 33 & 55,0 \\
Kurang & 27 & 45,0 \\
\hline Total & 60 & 100 \\
\hline
\end{tabular}

Table 3 shows that the frequency distribution of respondents based on physical activity, namely respondents with good physical activity amounted to $33(55.0 \%)$, respondents with less physical activity amounted to 27 $(45.0 \%)$.

Table 4. Frequency Distribution of Respondents Based on Dementia $(n=60)$

\begin{tabular}{lll}
\hline Demensia & Jumlah & Presentase (\%) \\
\hline Baik & 30 & 50,0 \\
Ringan & 21 & 35,0 \\
Buruk & 9 & 15,0 \\
\hline Total & 60 & 100 \\
\hline
\end{tabular}

Table 4 shows the frequency distribution of respondents based on dementia, namely respondents with good dementia categories totaling $30(50.0 \%)$, respondents with mild dementia categories totaling 21 (35.0\%), respondents with poor dementia categories amounting to $9(15.0 \%)$.

Table 5 Relationship between Sex and Dementia

\begin{tabular}{|c|c|c|c|c|c|c|}
\hline \multirow{3}{*}{ Jenis Kelamin } & \multicolumn{3}{|c|}{ Demensia } & \multirow{2}{*}{\multicolumn{2}{|c|}{ Total }} & \multirow{3}{*}{ p value } \\
\hline & \multirow{2}{*}{$\begin{array}{l}\text { Baik } \\
\mathrm{f}\end{array}$} & \multirow{2}{*}{$\begin{array}{l}\text { Ringan } \\
\mathrm{f}\end{array}$} & Buruk & & & \\
\hline & & & f & f & $\%$ & \\
\hline Laki-laki & 22 & 13 & 8 & 43 & 100 & \\
\hline Perempuan & 8 & 8 & 1 & 17 & 100 & 0,310 \\
\hline Total & 30 & 21 & 9 & 60 & 100 & \\
\hline
\end{tabular}

Table 5 Relationship between Sex and Dementia

Based on the results of the analysis in table 5, it can be seen that of the 43 male respondents, there were 22 respondents with good dementia, 13 respondents with mild dementia, and 8 respondents with bad dementia. Of the 17 female respondents, there were 8 respondents with good dementia, 8 respondents with mild dementia, and 1 respondent with bad dementia. Based on the Chi Square test, -value $=0.310(>$ 0.05) which means that there is no relationship between sex and dementia. 
Table 6 Relationship of Age Category with

Dementia

\begin{tabular}{llllllll}
\hline \multirow{2}{*}{ Kategori Usia } & \multicolumn{3}{l}{ Demensia } & \multicolumn{3}{l}{ Total } & $p v$ \\
\cline { 2 - 6 } & Baik & Ringan & Buruk & & \\
\cline { 2 - 6 } & $\mathrm{f}$ & $\mathrm{f}$ & $\mathrm{f}$ & $\mathrm{f}$ & $\%$ & \\
\hline Lansia awal & 28 & 10 & 2 & 40 & 100 & 0,0 \\
Lansia akhir & 2 & 11 & 7 & 20 & 100 & \\
\hline Total & 30 & 21 & 9 & 60 & 100 \\
\hline
\end{tabular}

Based on the results of the analysis in table 6, it can be seen that from 40 respondents in the early elderly age category, there were 28 respondents with good dementia, 10 respondents with mild dementia, and 2 respondents with bad dementia. Of the 20 respondents in the late elderly age category, there were 2 respondents with good dementia, 11 respondents with mild dementia at Respati Indonesia University, and 7 respondents with bad dementia. Based on the Chi Square test, it was found that -value = $0.000(<0.05)$, which means that there is a relationship between sex and dementia.

Table 7 Relationship of Physical Activity with

Dementia

\begin{tabular}{llllllll}
\hline & \multicolumn{3}{l}{ Demensia } & \multicolumn{3}{l}{ Total } & p value \\
\cline { 2 - 6 } Aktivitas Fisik & Baik & & Ringan & Buruk & & & \\
\cline { 2 - 6 } & $\mathrm{f}$ & $\mathrm{f}$ & $\mathrm{f}$ & $\mathrm{f}$ & $\%$ & \\
\hline Baik & 26 & 5 & 2 & 33 & 100 & \multirow{2}{*}{0,000} \\
Kurang & 4 & 16 & 7 & 27 & 100 & \\
\hline Total & 30 & 21 & 9 & 60 & 100 & \\
\hline
\end{tabular}

Based on the results of the analysis in table 5.7, it can be seen that from 33 respondents with good physical activity there were 26 respondents with good dementia, 5 respondents with mild dementia, and 2 respondents with bad dementia. Of the 27 respondents with less physical activity, there were 4 respondents with good dementia, 16 respondents with mild dementia, and 7 respondents with bad dementia. Based on the Chi Square test, it was found that -value = $0.000(<0.05)$, which means that there is a relationship between physical activity and dementia.

\section{Discussion}

The results showed that of the 43 male respondents, there were 22 respondents with good dementia, 13 respondents with mild dementia, and 8 respondents with bad dementia. Of the 17 female respondents, there were 8 respondents with good dementia, 8 respondents with mild dementia, and 1 respondent with bad dementia. Based on the Chi Square test, -value $=0.310(>$ 0.05) which means that there is no relationship between sex and dementia. This result is reinforced by the results of research conducted by Rinajumita (2011) showing that there are more male respondents $(56.7 \%)$ compared to female respondents. The results 
of research conducted by Mery (2012) at the Tresna Werdha Teratai Social Home in Palembang showed the same results that there were more male respondents $(60 \%)$ than female respondents (40\%). Likewise with the results of research conducted by Eka (2012), where the number of respondents who are male is more (58\%) than respondents who are female $(42 \%)$. Factors that influence this research is gender factor. The prevalence of Alzheimer's dementia is higher in men than women of the same age (Dye RV, Miller KJ, et al 2012). Estrogen is a protective factor against dementia because it has been found to modulate neurogenesis (McClure RE, Barha CK, et al., 2013) and activate new neurons as a cognitive response in the hippocampus (Galea LA, Wainwright SR, et al., 2013). The volume of the hippocampus that is lost with the aging process is accelerated. (Goto M, Abe O, et al., 2011). This shows that the life expectancy of women is higher. The results of the 2010 Population Census recorded that the life expectancy of women was 71.74 years, higher than that of men, which was 67.51 years (Central Bureau of Statistics, 2014). Research conducted by the University of Respati Indonesia by Nafidah (2014) in South Jakarta also found that of 118 respondents (elderly), 60.2\% were women while $39.8 \%$ were men. Dementia is more common in men, the incidence of dementia in men is greater than in women. However, there is no significant difference between gender with the incidence of dementia, this shows that both men and women have the same opportunity to develop dementia (Alzheimers' disease, 2011).

Relationship between Age and Dementia The results showed that from 40 respondents in the early elderly age category, there were 28 respondents with good dementia, 10 respondents with mild dementia, and 2 respondents with bad dementia. Of the 20 respondents in the late elderly age category, there were 2 respondents with good dementia, 11 respondents with mild dementia, and 7 respondents with bad dementia. Based on the Chi Square test, it was found that - value $=0.000(<0.05)$, which means that there is a sex relationship with dementia. The results of the analysis get the age factor is one that has a risk of dementia. The higher the age of the respondent, the higher the risk of dementia (Japardi, 2013). This is in line with previous research that the number of elderly people who experience dementia is greater at the age of 60-75 years, namely (75\%) (Marhamah, 2009). Based on research by Roan (2009) stated that dementia 
can also occur at any age, but more in the elderly for the age range of 65-74 years (50\%). The results of Dian's research (2012) also stated that the elderly aged 60 years and over the prevalence of dementia will double for every 5 years of age increase. Data from the World Health Organization in 2013, shows that dementia is experienced by the elderly aged $60-74$ years by $15-20 \%, 75-85$ years by $5-15 \%$. Based on statistical analysis, it was concluded that there was a significant difference in the average MMSE score of the elderly aged $60-75$ years with age $>76$ years. The older the age, the greater the prevalence and the more severe the type of dementia experienced by the elderly. This is because age is a major risk factor for dementia (Japardi, 2013).

Relationship between Physical Activity and Dementia The results showed that of the 33 respondents with good physical activity, there were 26 respondents with good dementia, 5 respondents with mild dementia, and 2 respondents with poor dementia. Of the 27 respondents with less physical activity, there were 4 respondents with good dementia, 16 respondents with mild dementia, and 7 respondents with bad dementia. Based on the Chi Square test, it was found that - value $=0.000(<0.05)$, which means that there is a relationship between physical activity and dementia. This study is in line with Sharkey (2011) that at the age of 60 years and retirement has time to increase activity, although it can decrease with age. Sports gerontologists have shown that fitness or activity can improve even after the age of 70. This is reinforced by research (Ismayanti, 2013) which states that the level of physical fitness increases until the age of 30 years and after 30 years there will be a gradual decline in fitness levels caused by diseases suffered by the elderly, making it difficult for the elderly to carry out activities. This is also corroborated by the opinion of McKhan (2010, in Pangulu, 2015) that one of the reasons women live longer than men in Panti is that generally women have more responsibility for cooking, cleaning, and shopping for activities that require a lot of walking, bending, standing. and lift. The elderly who have been inactive for a long time usually have less flexibility, muscle strength and endurance. This situation in addition to reducing organ function also increases the risk of various degenerative diseases, including hypertension, diabetes mellitus, coronary artery disease and accidents. Other studies have also shown that exercise training that increases activity at a 
higher level is sufficient to eliminate these risks. The various components that need to be carried out in the exercise are self-efficacy. Defense, strength, flexibility and endurance training (Darmojo, 2011). Healthy individuals are individuals who have the ability to carry out activities to meet needs such as standing, walking, and working. Activity is an energy or state to move or to meet the needs of life. The ability of a person's activity is influenced by the adequacy of the respiratory system, muscles and bones or joints (Tarwoto and Wartonah, 2010). Physical activity is a movement carried out by the body's muscles and supporting systems. The amount of energy needed depends on the number of muscles that move, the duration and weight of the work done (Almatsier, 2011). According to Jones and Rose (2015) by carrying out a short-term physical activity program such as physical exercise can bring significant improvements in the performance of the cognitive function of the elderly. In addition, by doing physical activity regularly and periodically including walking will make cognitive function better. This is because physical activity can maintain optimal blood flow and deliver nutrients to the brain. If the elderly do not do physical activity regularly, the blood flow to the brain decreases, and will cause the brain to lack oxygen. (Marhamah, 2012). Physical activity is also thought to stimulate nerve growth which may inhibit cognitive function decline in the elderly (Muzamil, Afriwardi, \& Martini, 2014). According to Kirk-Sanchez and McGough (2013) when doing physical activity, the brain will be stimulated so that it can increase a protein in the brain called Brain Derived Neutrophic Factor (BDNF). This BDNF protein plays an important role in keeping nerve cells fit and healthy. However, if BDNF levels are low, it will cause senility (Antunes, 2016). According to the National Institute on Aging (2009), physical activity can be done by moving / moving the body such as gardening, walking, and climbing stairs.

\section{Conclusion}

Based on the results of research conducted on 60 respondents about factors related to dementia in the elderly at the Cakung District Health Center in 2020. The researchers can draw the following conclusions: Respondents involved in this study were mostly male with an average age The average is the early elderly, the elderly who do more physical activity so that the average level of physical activity is still in the good category. The 
study showed that there was a relationship between age and physical activity with dementia and there was no relationship between gender and dementia.

\section{Bibliography}

Albert, S.M. \& Freedman, V.A. 2011. Public health and aging; maximizing function and well-being. New York: Springer Publishing Company.

Alzheimer's Disease International, Alzheimer's Disease Australia. 2014. Dementia In The Asia Pacific Region. London: Alzheimer's Disease International.

Ambardini, L. 2014. Aktifitas Fisik Pada Lanjut Usia. Yogyakarta: Staff Pengajar UNY.

Aminuddin, T., 2015. Pengaruh Senam Otak Terhadap Penurunan Tingkat Demensia Pada Lansia. Jurnal Penelitian Universitas Negeri Semarang

Asrori, N., \& Putri, O. O. 2014. Panduan Perawatan Pasien Demensia di Rumah. Malang: Umm press.

Azizah, Lilik Ma'rifatul. 2011. Keperawatan Lanjut Usia. Yogyakarta : Graha Ilmu

British Heart Foundation National Centre. 2014. Physical Activity for Children and Young People. Physical Activity and Health. United Kingdom.

Brown, W. J., Bauman, A. E., Bull, F. C., \& Burton, N. W. 2013. Development of evidence-based physical activity recommendations for adults (18-64 years): report prepared for the Australian Government Department of Health, August 2012.
Garber, Carol Ewing., et al. 2011. Quantity and Quality of Exercise for Developing and Maintaining Cardiorespiratory, Musculoskeletal, and Neuromotor Fitness in Apparently Healthy Adults: Guidance for Prescribing Exercise.

Gluhm, S., BA, Goldstein, J., BS, Loc, K., $\mathrm{MD}$, et al. 2013. Cognitive performance on the Mini-Mental State Examination and the Montreal Cognitive Assessment Across the Healthy Adult Lifespan. National Institutes of Health, 1-11

Hidayaty Dian Fithria. 2012. Hubungan Aktivitas Fisik Dan Aktivitas Kognitif Terhadap Kejadian Demensia Pada Lansia Di Kelurahan Sukabumi. (Skripsi). Fakultas Kedokteran dan Ilmu Kesehatan. UIN Syarif Hidayatullah Jakarta.

Kholifah, Siti Nur. 2016. Keperawatan Gerontik. Jakarta Selatan: Kemenkes RI

Killin, L. O., starr, J. M., shiue, I. J., \& Russ, C. T. 2016. Environmental risk factor for dementia: A Sistematic Review. BMC geriatric, 16:175, 1-28

Nafidah, N. 2014. Hubungan Antara Aktifitas Fisik dengan Tingkat Kognitif Lanjut Usia di Panti Sosial Tresna Wredha Budi Mulia 4 Marga Guna Jakarta Selatan. Skripsi. UIN Jakarta.Keperawatan

Notoatmodjo S. 2012. Promosi Kesehatan dan Perilaku Kesehatan. Jakarta: PT Rineka Cipta. Notoatmodjo, S. 2010. Metodologi Penelitian Kesehatan. Jakarta : Rineka Cipta

Nursalam. 2014. Manajemen Keperawatan: Aplikasi Dalam Praktik Keperawatan 
Profesional. Jakarta: Salemba Medika.

Pieter, Herri Zan, Bethsaida Janiwarti, dan Ns. Marti Saragih. 2011. Pengantar Psikopatologi untuk Keperawatan. Jakarta: Kencana.

Sugiyono. 2014. Metode Penelitian Pendidikan Pendekatan Kuantitatif, Kualitatif, dan R\&D. Bandung: Alfabeta.

Sunaryo, dkk. 2016. Asuhan Keperawatan Gerontik. Yogyakarta: Andi.

Suwarni, S., Setiawan, S., \& Syatibi, M. M. 2017. Hubungan Usia Demensia Dan Kemampuan Fungsional Pada Lansia. Jurnal Keterapian Fisik
Wahyudi, Nugroho. 2011. Keperawatan Gerontik dan Geriatrik. Edisi 3. Jakarta : EGC

World Health Organization. 2011. The World Medicine Situation 2011 3ed. Rational Use of Medicine. Geneva

Yudhanti Evani. 2016. Hubungan Aktivitas Fisik Dengan Kejadian Demensia Pada Lansia Di Balai Pelayanan Sosial Tresna Werdha Yogyakarta Unit Budi Luhur. Program Studi Keperawatan Stikkes Aisyiyah Yogyakarta. 